\section{Bilko M., Permyakova A., Pashkovskiy A., Kalmykova I., Haidai I.}

\title{
STUDYING THE INFLUENCE OF YEAST STRAINS ON THE AROMA OF WINES MADE FROM GRAPE OF ZAGREY VARIETY
}

У роботі наведені дані про вплив рас дріжджів на ароматичні і окислювально-відновні властивості білих сухих виноматеріалів, виготовлених з винограду нового покоління сорту Загрей селекцї Національного наукового центру «Інституту виноградарства і виноробства імені В. С. Таїрова» (ННЦ «ІВіВ ім. В. С. Таірова», смт. Таїрове, Одеська обл., Україна) в умовах мікровиноробства.

Сорт винограду Загрей був виведений шляхом схрещування сортів Аліготе та Овідіопольський для розширення сортименту українського винограду, однак відсутність досліджень в напрямку використання для виноробства стримують широке впровадження його у виробництво.

Матеріалами були білі сухі виноматеріали, виготовлені з винограду сорту Загрей із застосуванням рас дріжджів Vitilevur 58W3, Sauvignon, Elixir, EC1118, Cross Evolution (Франція). Ці раси дріжджів характеризуються різною здатністю до синтезу ароматутворюющих речовин, що впливають на формування букета вин і на розкриття ароматичного потенціалу сорту винограду.

У виноматеріалах досліджували органолептичні характеристики за 8-бальною шкалою із застосуванням дескрипторної системи, масові концентрацї̈ речовин ароматутворюющого комплексу, фенольних сполук, рівень редокс-потенціалу та інші показники окисно-відновного стану виноматеріалів.

Встановлено, що використання раси дріжджів Vitilevur 58W3 дозволяє виявляти сортові особливості винограду сорту Загрей, надаючи йому квітково-фруктову ноту. А раси дріжджів Elixir $i$ Saиvignоп урізноманітнюють сортовий аромат, надаючи йому тонких цитрусових нот лимона і грейпфрута, липових відтінків і інших екзотичних фруктів. Отримані дані органолептичних характеристик виноматеріалів добре узгожуються з результатами дослідження речовин ароматичного комплексу виноматеріалів. Так, в виноматеріалах, де була використана раса дріжджів Vitilevur 58W3, переважали терпенові спирти, a Elixir i Sauvignon - складні ефіри.

Доведено, що застосування різних рас дріжджів істотно не впливає на окислювально-відновний потенціал $і$ вміст фенольних сполук.

Результати дослідження дозволяють рекомендувати раси дріжджів 58W3, Elixir i Sauvignоп для виробництва високоякісних вітчизняних білих вин з винограду сорту Загрей селекиї ННЦ «ІВіВ ім. В. С. Таїрова».

Ключові слова: виноград сорту Загрей, раса дріжджів, ароматичний потенціал сорту винограду, білі сухі виноматеріали.

\section{Introduction}

The primary factor in determining the effectiveness and profitability of vineyards is the properly selected range. A priority task of the grapes-wine industry is the expansion of planting grapes for the intensification of natural table wines production [1].

Researchers form the National Scientific Center «Institute of Viticulture and Wine-Making named after V. E. Tairov» (NSC «IV\&WM named after V. E. Tairov», settlement of Tairove, Odessa Oblast, Ukraine) launched a number of promising new varieties of the new breeding generation that are resistant to common fungal diseases. This makes it possible to reduce the consumption of preparations to protect plants and bring down cultivation costs while obtaining ecologically-clean grapes for the production of wines [2,3].

Introduction of new varieties of grapes requires their comprehensive studying, therefore, it is a relevant task to undertake a research aimed to determine the feasibility of applying the bred grapes in the process of implementing the technology of table wines.

\section{The object of research and its technological audit}

The object of research is the grape of Zagrey variety, bred at NSC «IV\&WM named after V. E. Tairov», resulting from the cross-breeding of varieties Ovidiopol and Aligote [4]. It is characterized (Table 1) by a simple aroma and taste, which necessitates the search to find ways of revealing the aromatic potential of the variety in order to extend the range of wines and to promote competition among producers.

The wine market commonly utilizes strains of yeast, which can be used to produce wines with the predefined aromatic characteristics, capable to enhance the varietal features of grapes $[5,6]$.

In this work, we used the yeast strains Vitilevur 58W3, Sauvignon, Elixir, EC1118, Cross Evolution (France), which are characterized by a varying capability to synthesize the aroma-forming substances that influence the bouquet of wines. Characteristics of the used yeast strains are given in Table 2. 
Table 1

Characteristics of the Zagrey grape variety

\begin{tabular}{|l|c|}
\hline \multicolumn{1}{|c|}{ Indicator } & Characteristic \\
\hline Ripening period & mid-late \\
\hline Growth strength of one-year shoots & medium \\
\hline Aging of vines & good \\
\hline Winter resistance & high \\
\hline Frost resistance, ${ }^{\circ}$ C & $-23--25$ \\
\hline Resistance against main fungal diseases, point & 7 \\
\hline $\begin{array}{l}\text { Bunch: } \\
\text { Mass, g } \\
\text { Shape } \\
\text { Density }\end{array}$ & medium 140-200 \\
\hline Harvest yield, c/ha & cylindric-conic, sometimes with a wing \\
\hline $\begin{array}{l}\text { Berry: } \\
\text { Mass, g } \\
\text { Shape } \\
\text { Color } \\
\text { Aroma and taste }\end{array}$ & medium \\
\hline Sugar content of berry juice, g/dm ${ }^{3}$ & medium 1.6 \\
\hline Acidity, g/dm ${ }^{3}$ & round \\
\hline
\end{tabular}

Table 2

Characteristics of yeast strains

\begin{tabular}{|c|l|}
\hline Strain of yeast & \multicolumn{1}{|c|}{ Features of yeast strain and fermentation conditions } \\
\hline Elixir & $\begin{array}{l}\text { Exhibits aromatic (terpenes, C13 norizoprenoids) potential of the } \\
\text { varieties Traminer, Muscat, Chardonnay ( } \beta \text {-glucosidase activity) and } \\
\text { thiol compounds (3MH and A3MH). That allows an increase in the } \\
\text { complexity and subtlety of wines; high potential to synthesize esters } \\
\text { of fatty acids, which are responsible for the fruity scents }\end{array}$ \\
\hline $58 W 3$ & $\begin{array}{l}\text { Specially adapted yeast strain to develop the aromas of white wines } \\
\text { made from grapes of varieties Muscat, Gewürztraminer, Pinot Gris. } \\
\text { Adds aromatic intensity and complexity to wine, contributes to the } \\
\text { completeness of taste }\end{array}$ \\
\hline Sauvignon & $\begin{array}{l}\text { Displays the aroma of thiol compounds (3MH and A3MH), which } \\
\text { make allows an increase in the complexity and subtlety of wines }\end{array}$ \\
\hline Lalvin EC 1118 & Neutral strain of yeast, clean aroma, the low level of synthesis of esters \\
\hline Cross Evolution & $\begin{array}{l}\text { Increases the aromatic potential of grape varieties. High aromatic } \\
\text { properties: a good balance between a fresh fruity aroma and floral } \\
\text { tones. Expedient to use for the varieties of grapes, which are poor } \\
\text { in the content of aroma predecessors }\end{array}$ \\
\hline
\end{tabular}

To achieve the set aim, the following tasks have been solved:

1. To develop table dry white wine materials from the grapes of Zagrey variety using different strains of yeast, and to conduct chemicaltechnological estimation of the wine materials from the grapes of Zagrey variety.

2. To investigate effect of various strains of yeast on the formation of organoleptic quality indicators of wine materials from the grapes of Zagrey variety.

3. To compare the content of substances in the aromatic complex of the obtained wine materials.

4. To explore the oxidation-reducing state of wine materials and to run a comparative analysis of the samples.

\section{Research of existing solutions of the problem}

Despite the huge potential of grape of the genus Vitis vinifera, the varieties of intraspecific origin cannot overcome genetic barriers in resistance against the adverse effects of the environment [5].

These varieties often do not meet the requirements of production, due to frequent crop losses associated with the fact that the viticulture of Ukraine is largely developed in the zone with a continental arid climate. At the same time, the climatic conditions of raw materials zones are characterized by frosty (often snowless) winters and minimum temperatures to minus $26-28{ }^{\circ} \mathrm{C}$, late spring frosts and prolonged droughts with a large deficit of moisture in soil and air [7].

Given this, there is a need for such a varietal structure that would really ensure annual stable yields, high quality of wines at a significant reduction in the technological pollution to the environment

The use of such varieties at industrial scale would make it possible to expand the varietal composition of viticulture, to cultivate ecologically-clean grapes and to improve the quality of wine production.

A problematic issue related to the application of Zagrey grape variety in wine technology is the lack of knowledge on this variety in terms of its processing for different types of wines. There are no studies aimed at finding technological methods that contribute to the manifestation of varietal characteristics of a given variety of grape.

The strains of yeast used in this study can enhance the potential of the variety or enrich it through the synthesis of certain classes of secondary and side products of fermentation.

\section{The aim and objectives of research}

The aim of research is to identify the aromatic characteristics of wine materials obtained from the Zagrey variety of the new generation bred at NSC «IV\&WM named after V. E. Tairov» using different strains of yeast for the production of white table wines.
The scientific literary has over recent time provided more research results related to technological estimation of the new grape bred at NSC «IV\&WM named after V. E. Tairov», aimed at choosing a direction of its use [3, 8]

At the same time, the bred grape is often characterized by an unpronounced varietal aroma, which may compromise its market value.

One of the techniques to improve the organoleptic characteristics of wine materials is to apply the strains of yeast that could help control the quality of wines [9].

Numerous scientific studies have established the substances responsible for the aroma of grapes [10-14]. They are localized in the skin of grapes and in the adjacent layers of pulp.

These are mostly terpene alcohols, which, together with their derivatives, form the basis of the so-called essential oil of grapes and the predecessors of thiol aromas C13 norizoprenoids. 
In dry wines, terpene alcohols undergo significant changes, however, their concentration remains high enough to be perceived by sense organs.

During fermentation, under the action of yeast, there form the secondary products, which include esters, volatile acids, aldehydes, etc. They are the background flavor components of wine and, together with terpene alcohols, create the aroma of wine [10-13].

Esters render wine fruit shades. Aldehydes in table wines are represented for $90 \%$ by acetaldehyde. In young table wines, acetic aldehyde cannot significantly affect the aroma of wines because its concentration does not exceed the threshold. At acetaldehyde concentrations above $100 \mathrm{mg} / \mathrm{dm}^{3}$, wines acquire a tone of oxidation, which significantly reduces quality of table wines [15].

Given the above, it is of a scientific interest to study the aromatic complex of table wine materials, as well as their oxidation-reducing state from the newly-bred variety of grapes.

\section{Methods of research}

To obtain dry white wine materials, the grapes were processed at a temperature of $14 \ldots 17{ }^{\circ} \mathrm{C}$ using a «white» mode. The resulting wort was sulphated by introducing Kadifit at the rate of $75 \mathrm{mg}$ of the total $\mathrm{SO}_{2}$ content/ $\mathrm{dm}^{3}$. The wort was aged over $18 \ldots 24$ hours at a temperature of $15 \ldots 18{ }^{\circ} \mathrm{C}$. After removing the sediment, it was sent to fermentation. Yeast was introduced to the wort at a rate of $0.3 \mathrm{~g} / \mathrm{dm}^{3}$ of wort. Dry yeast was pre-activated. In the process of fermentation, the temperature was maintained at a level of $18 \ldots 20{ }^{\circ} \mathrm{C}[16]$.

After clarification and removal from yeast, we maintained in the wine materials a mass concentration of free sulfur dioxide at a level of $25 \ldots 30 \mathrm{mg} / \mathrm{dm}^{3}$.

We explored in the wine materials:

- organoleptic characteristics based on an 8-point scale and using a descriptor system;

- mass concentrations of substances in the aromatic complex of wine materials: terpene alcohols, ethers, and aldehydes;

- the content of phenolic compounds;

- the level of redox potential;

- $\Delta \mathrm{Eh}-$ an absolute gain in OR-potential:

$$
\Delta E h=E h_{1}-E h_{2},
$$

where $E h_{1}$ and $E h_{2}$ are the starting and resulting value of a wine material potential before and after titration with a solution of iodine, respectively, $\mathrm{mV}$; $\omega$ is the specific gain in potential: the quotient derived by dividing the gain in potential $\Delta E h$ by the amount of iodine $1 \mathrm{M}\left(\mathrm{cm}^{3}\right)$ that was used for the titration $-\omega=\Delta E h / 1 M$; $W$ is an oxidation indicator, characterizing the oxidation state of phenolic substances in a wine material according to the accepted winemaking techniques [16].

\section{Research results}

6.1. Studying the aroma-forming complex of wine materials from grape of Zagrey variety. An analysis of the results of physical-chemical indicators of the examined samples of wine materials meets the requirements of normative documents for this type of product (Table 3 ).
Mass concentration of sugars did not exceed $3.0 \mathrm{~g} / \mathrm{dm}^{3}$.

Studying the aroma-forming complex of wine materials has allowed us to determine differences in the contents of their basic classes (Table 4).

Table 3

Physical-chemical indicators of wine materials

\begin{tabular}{|c|c|c|c|c|c|}
\hline \multirow{2}{*}{$\begin{array}{c}\text { Experimental } \\
\text { variant }\end{array}$} & \multirow{2}{*}{$\begin{array}{c}\text { Volumetric } \\
\text { share of } \\
\text { alcohol, \% }\end{array}$} & $\begin{array}{c}\text { Contents } \\
\text { titrated } \\
\text { acids, } \\
\mathrm{g} / \mathrm{dm}^{3}\end{array}$ & $\begin{array}{c}\text { volatile } \\
\text { acids, } \\
\mathrm{g} / \mathrm{dm}^{3}\end{array}$ & $\begin{array}{c}\mathrm{free} \text { sulphur } \\
\text { dioxide, } \\
\mathrm{mg} / \mathrm{dm}^{3}\end{array}$ & $\begin{array}{c}\text { relative } \\
\text { units }\end{array}$ \\
\hline Elixir & 11.8 & 5.0 & 0.37 & 12.8 & 3.14 \\
\hline 58W3 & 11.8 & 5.0 & 0.32 & 19.2 & 3.12 \\
\hline Sauvignon & 12.0 & 5.2 & 0.31 & 12.8 & 3.10 \\
\hline EC 1118 & 11.8 & 5.0 & 0.38 & 19.2 & 3.17 \\
\hline Cross Evolution & 12.1 & 5.0 & 0.31 & 12.8 & 3.12 \\
\hline
\end{tabular}

Table 4

Indicators of the aromatic complex of wine materials

\begin{tabular}{|c|c|c|c|c|c|}
\hline \multirow{3}{*}{$\begin{array}{l}\text { Experimental } \\
\text { variant }\end{array}$} & \multicolumn{5}{|c|}{ Contents, mg/dm 3} \\
\hline & \multirow{2}{*}{ aldehydes } & \multicolumn{3}{|c|}{ terpene alcohols } & \multirow{2}{*}{ esters } \\
\hline & & free & bound & total & \\
\hline Elixir & 35.2 & 3.18 & 2.46 & 5.64 & 81.0 \\
\hline 58W3 & 26.4 & 5.46 & 2.51 & 7.97 & 56.2 \\
\hline Sauvignon & 30.8 & 4.22 & 2.32 & 6.54 & 98.6 \\
\hline EГ 1118 & 30.8 & 3.90 & 3.09 & 6.99 & 70.3 \\
\hline Cross Evolution & 17.6 & 4.60 & 1.82 & 6.42 & 62.0 \\
\hline
\end{tabular}

When using the yeast strain $58 \mathrm{~W} 3$, the wine materials were dominated by terpene alcohols - true carriers of flavor of the grapes, mostly in the free form; this strain of yeast is characterized by the manufacturer as having the character of a terpene. The lowest value of this indicator was observed in the sample that contained Elixir $-5.64 \mathrm{mg} / \mathrm{dm}^{3}$. When wort was fermented on the yeast strains Elixir and Sauvignon, the wine materials had the highest content of esters in comparison with other samples.

Contents of aldehydes did not exceed the aromatic threshold, indicating a lack of oxidation tones in the samples.

The results of research into flavor of the samples showed that all samples were quite intense in taste and had a pleasant harmonious acidity. The most typical flavor was noted in the sample that contained Elixir, and the long-lasting taste - in the sample that contained Cross Evolution (Fig. 1).

The samples prepared using the yeast 58W3, Elixir and Sauvignon were noted by tasters to have the most intense aroma, dominated by flowery-fruit tones.

Matching the shades of wine materials aromas by using a descriptor evaluation revealed differences depending on the strains of yeast used (Fig. 2).

In terms of aroma intensity of wine materials, yeast was distributed in the following order from more to less multi-faceted: Sauvignon $\rightarrow$ Elixir $\rightarrow$ EC1118 $\rightarrow$ Cross Evolution $\rightarrow$ 58W3.

The application of the yeast strains Sauvignon, Elixir added flavor to wine materials from the grape of Zagrey variety, which is characterized by a weak simple fragrance, 
shades of exotic fruits, citron, apple, mint and licorice. Thus, the wine material produced using the yeast strain Elixir had a bright floral fragrance with subtle citrus notes of lemon and grapefruit and other exotic fruits, fresh and harmonious taste. The application of the yeast Sauvignon emphasized apple tones in the wine material, as well as white cherry with lemon-linden shades. Using the yeast strains 58W3, Cross Evolution and EC1118 slightly changed the fragrance of wine materials: the strain 58W3 rendered shades of linden flowers with hints of peony; Cross Evolution -barberry, lychee, and gooseberry; and EC1118 - lollipop, watermelon, and white plum.

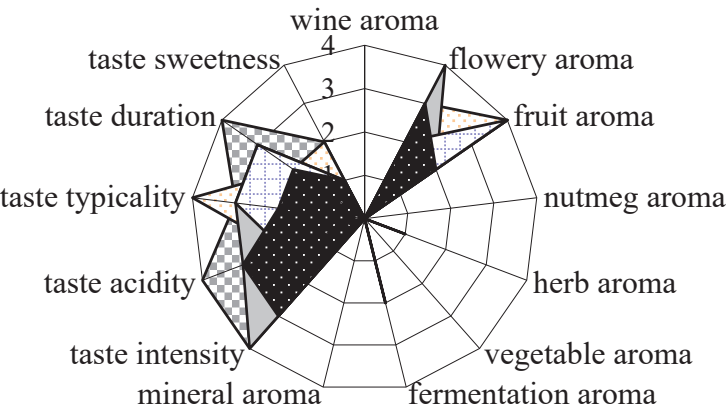

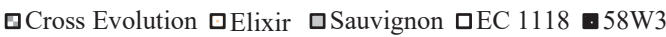

Fig. 1. Effect of using the strains of yeast on the formation of flavor in wine materials

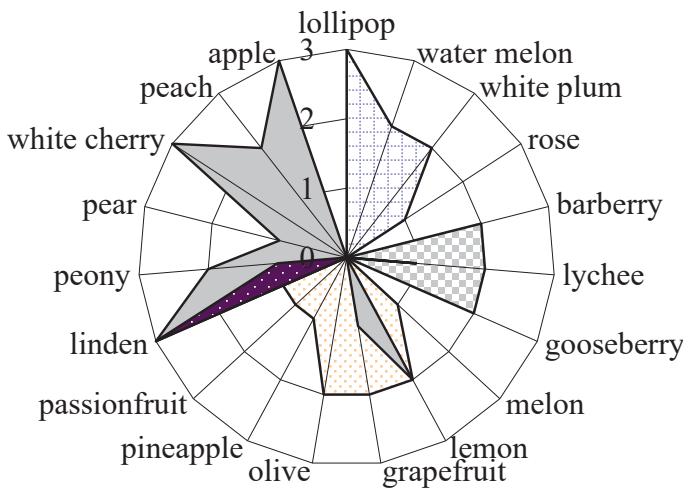

$\square$ EC $1118 \square$ Cross Evolution $\square$ Elixir $\square$ Sauvignon $\square 58 \mathrm{~W} 3$

Fig. 2. Effect of yeast strains on the formation of aroma shades of wine materials

6.2. Examining the effect of yeast strains on the oxidation-reducing state of wine materials. It is known from study [17] that yeast can synthesize substances (for example, yeast glutathione, sulfur dioxide, etc.) that indirectly influence the oxidation-reducing (OR) state of wine materials, which could lead to the oxidation of substances in the aromatic complex of wine materials. At the same time, phenolic substances are the initiators of oxidation and their elevated content can also lead to the oxidation of wine materials.

The level of OR indicators for the complex of wine materials point to the unoxidized state of all wine materials regardless of the strains of yeast used (Table 5).
Table 5

Indicators for the oxidation-reducing state of wine materials wine and the content of phenolic substances

\begin{tabular}{|c|c|c|c|c|c|}
\hline $\begin{array}{c}\text { Experimental } \\
\text { variant }\end{array}$ & $\begin{array}{c}\text { Content of phe- } \\
\text { nolic substances, } \\
\mathrm{mg} / \mathrm{dm}^{3}\end{array}$ & $\begin{array}{c}E h_{0 \prime} \\
\mathrm{mV}\end{array}$ & $\begin{array}{c}\Delta E h_{h_{1}} \\
\mathrm{mV}\end{array}$ & $\begin{array}{c}W_{\prime^{\prime}} \\
\mathrm{mV} \cdot \mathrm{dm}^{3} / \mathrm{mg}\end{array}$ & $\begin{array}{c}\omega_{,} \\
\mathrm{mV} / \mathrm{cm}^{3}\end{array}$ \\
\hline Elixir & 516 & 190 & 190 & 0.368 & 94.2 \\
\hline $58 W 3$ & 448 & 168 & 205 & 0.375 & 105.0 \\
\hline Sauvignon & 450 & 201 & 171 & 0.380 & 106.9 \\
\hline EC 1118 & 446 & 200 & 160 & 0.359 & 81.4 \\
\hline Cross Evolution & 446 & 206 & 164 & 0.368 & 82.0 \\
\hline
\end{tabular}

The initial redox potential varied within $190 \ldots 206 \mathrm{mV}$, $\Delta E h-160 \ldots 190 \mathrm{mV}$. The values for oxidation indicator of phenolic compounds $\mathrm{W}$ were close among themselves: $0.36 \ldots 0.38 \mathrm{mV} \cdot \mathrm{dm}^{3} / \mathrm{mg}$. And only the elevated values of specific potential gain in the samples that contained 58W3 and Sauvignon, 105.0 and $106.9 \mathrm{mV} / \mathrm{cm}^{3}$, respectively, pointed to the potential for the oxidation of these wine materials in comparison with other samples.

\section{SWOT analysis of research results}

Strengths. Using the strains of yeast makes it possible to control the aroma of white table wine materials from the grape of Zagrey variety, newly-bred at NSC «IV\&WM named after V. E. Tairov», which is characterized by a simple neutral flavor, enhancing varietal characteristics, or enriching with flower and fruit notes.

Weaknesses. The strains of yeast may affect the OR-state of wine materials, synthesizing the respective substances into environment or sorb substances from a phenolic complex, which could indirectly influence the oxidation of substances in the aromatic complex. Thus, using the yeast Sauvignon made it possible to obtain the most saturated wine materials in their aroma; it, however, can lead to oxidation.

Opportunities. The study that we conducted has shown the possibility to utilize the Zagrey variety grape, newlybred at NSC «IV\&WM named after V. E. Tairov», for the production of table white wines, while using the strains of yeast would improve the quality of wines and their organoleptic characteristics.

Threats. When applying the examined strains of yeast in the production of white table wine materials, wineries require additional investments to purchase them; however, they ensure the guaranteed quality and expected result.

\section{Conclusions}

1. The result of this work is the prepared table dry white wine materials from the grapes of Zagrey variety, with an initial simple and weak grape flavor. We used different strains of yeast, which meet the requirements for a given type of product, with bright organoleptic features.

2. The organoleptic examination of samples that we conducted has revealed that the use of the yeast strain 58W3 makes it possible to reveal the floral notes of grapes of Zagrey variety, newly-bred at NSC «IV\&WM named after V. E. Tairov», while the yeast strains Sauvignon and Elixir render wine materials a multifaceted flavor of fruits and exotic fruits. That makes it possible to produce high- 
quality table white wines with interesting organoleptic characteristics.

3. It was established that the strains of yeast affect the content of substances in an aroma-forming complex of wine materials. The strain of yeast 58W3 in wine materials made from grapes of Zagrey variety emphasizes its varietal features due to the greater concentration of terpene alcohols - true carriers of the flavor of the grapes. When the wort was fermented on the strains of yeast Elixir and Sauvignon, the wine materials exhibited the highest content of esters in comparison with other samples, resulting in a multifaceted fragrance of the samples of wines.

4. The oxidation-reducing state of white dry wine materials is not considerably affected by the strain of yeast; however, a comparative analysis of values for specific potential gain of the sample indicated the greater oxidation susceptibility of wine materials that contained the yeast strains 58W3 and Sauvignon.

\section{References}

1. Avidzba A. M. Programma razvitiya vinogradarstva i vinodeliya v Ukraine v 2025 g. URL: http://www.info-library.com.ua/ libs/stattya/2773-programma-razvitija-vinogradarstva-i-vinodelija-v-ukraine-do-2025-g.html (Last accessed: 22.06.2018).

2. Rezul'taty i perspektivy selektsionnoy raboty / Vlasov V. V. et al. // Vinogradarstvo i vinodelie. 2012. No. 49. P. 16-23.

3. Tekhnologicheskaya otsenka vinograda sorta Shkoda i vybor napravleniya ego ispol'zovaniya / Kalmykova I. S. et al. // Kharchova nauka i tekhnologiva. 2014. No. 3. P. 62-67.

4. Ampelograficheskiy atlas sortov i form vinograda selektsii NNTS «IViV im. V. E. Tairova»/Vlasov V. V. et al. Kyiv, 2014. 138 p.

5. Tulaeva M. I. Sozdanie genofonda i uluchshenie sortimenta vinograda Ukrainy // Vinogradarstvo i vinodelie XXI veka. 2005. P. 55-60

6. Handbook of Enology. The Chemistry of Wine Stabilization and Treatments / Rib'ereau-Gayon P. et al. John Wiley \& Sons, 2006. 441 p. doi: http://doi.org/10.1002/0470010398

7. Formirovanie novogo genofonda vinograda Ukrainy, ustoychivogo protiv stressovykh faktorov sredy / Tulaeva M. I. et al. // Mobilizatsiya i sokhranenie geneticheskikh resursov vinograda, sovershenstvovanie metodov selektsionnogo protsessa. Novocherkassk, 2008. URL: http://vinograd.info/stati/stati/formirovanie-novogo-genofonda-vinograda-ukrainy-ustoychivogo-protiv-stressovyhfaktorov-sredy.html (Last accessed: 22.06.2018)

8. Trynkal O. V. Udoskonalennia tekhnolohii stolovykh bilykh vyn z sortiv vynohradu novoi vitchyznianoi selektsii: PhD thesis. Kyiv, 2016. 122 p.
9. The role of yeast in grape flavour development during fermentation: The example of Sauvignon blanc / Dubourdieu D. et al. // American Journal of Enology and Viticulture. 2006. Vol. 57. P. $81-88$.

10. Berger R. G. Flavours and Fragrances. Chemistry bioprigsing and sustainability. Berlin-Heidelberg: Spinger-Verlag, 2007. 648 p. doi: http://doi.org/10.1007/978-3-540-49339-6

11. Styger G., Prior B., Bauer F. F. Wine flavor and aroma // Journal of Industrial Microbiology \& Biotechnology. 2011. Vol. 38 No. 9. P. 1145-1159. doi: http://doi.org/10.1007/s10295011-1018-4

12. Aznar M. Prediction of Aged Red Wine Aroma Properties from Aroma Chemical Composition. Partial Least Squares Regression Models // Journal of Agricultural and Food Chemistry. 2003. Vol. 51, No. 9. P. 2700-2707. doi: http://doi.org/10.1021/jf026115z

13. Bil'ko M. V., Gerzhikova V. G. Nekotorye tekhnologicheskie aspekty upravleniya aromatom stolovykh vin // Vinograd. 2008. No.3. P. 26-27.

14. Levures - vins blancs. URL: http://ioc.eu.com/fr/fiches-produits/ vins-blancs/ (Last accessed: 22.06.2018).

15. Ronald J. C., Bakker J. Wine Flavour Chemistry. Blackwell Publishing, 2004. 326 p. doi: http://doi.org/10.1002/9780470995594

16. Metody tekhnokhimicheskogo kontrolya v vinodelii / ed. by Gerzhikova V. G. Simferopol', 2009. 304 p.

17. Bowyer P. K., Murat M.-L., Moine-Ledoux V. Glutathione Aroma Preservation in white/rosé wines // Practical Winery \& Vineyard Journal. 2010. P. 2-5.

Bilko Marina, PhD, Associate Professor, Department of Biotechnology of Fermentation and Wine Products, National University of Food Technologies, Kyiv, Ukraine, e-mail: aromat@ukr.net, ORCID: https://orcid.org/0000-0002-1122-4937

Permyakova Alyona, Department of Biotechnology of Fermentation and Wine Products, National University of Food Technologies, Kyiv,Ukraine,e-mail: alyonushka1405@gmail.com,ORCID:https:// orcid.org/0000-0003-3841-5474

Pashkovskiy Aleksandr, Postgraduate Student, Department of Wine Technology and Oenology, Odessa National Academy of Food Technologies, Ukraine, e-mail: sunnik14@yandex.ua, ORCID: http:// orcid.org/0000-0003-1882-7199

Kalmykova Iryna, PhD, Department of Wine Technology and Oenology, Odessa National Academy of Food Technologies, Ukraine, e-mail: iragaby@gmail.com, ORCID: https://orcid.org/0000-0002-3981-9385

Haidai Iryna, PhD, Department of Technology of Storage and Processing of Fruits and Vegetables, Uman National University of Horticulture,Ukraine,e-mail: gaydayira35@gmail.com,ORCID: https:// orcid.org/0000-0002-9202-0062 